\title{
Personal Branding Remaja di Era Digital
}

\author{
Ascharisa Mettasatya Afrilia \\ Program Studi Ilmu Komunikasi, Universitas Tidar, Magelang. \\ Email: mettaafrilia@untidar.ac.id
}

\begin{abstract}
Abstrak. Branding adalah hal yang umum dilakukan dalam dunia pemasaran. Branding dilakukan untuk membedakan satu produk dengan produk lainnya sehingga memunculkan cirinya yang khas. Seiring berkembangnya konteks branding tersebut, kini branding telah merambah ke banyak lini, termasuk dalam pengembangan diri seseroang. Hal inilah yang kemudian dikenal dengan istilah personal branding. Penelitian ini mengulas tentang analisis personal branding remaja yang direpresentasikan oleh Gita Savitri. Gita Savitri adalah sosok remaja yang digandrungi karena pemikirannya dalam menyikapi hal-hal tentang kehidupan remaja. Salah satu tujuan dilakukannya penelitian ini adalah untuk mengejawantahkan sudut pandang remaja dalam mendefinisikan jati dirinya. Hal ini menjadi niscaya karena eksistensi diri adalah hal mendasar yang pasti ada pada diri seseorang, termasuk remaja. Penelitian ini menggunakan metode deskriptif kualitatif yang didukung delapan konsep utama personal branding Peter Montoya. Hasil penelitian menunjukkan bahwa personal branding Gita Savitri memenuhi kedelapan konsep utama tersebut dan melingkupi tiga elemen utama personal branding, yaitu You, Promise, dan Relationship.
\end{abstract}

Kata kunci: personal branding, media sosial, remaja, Instagram, Gita Savitri.

\begin{abstract}
Branding is a common thing done in the world of marketing. Branding is done to distinguish one product with other products so that raises its distinctive characteristics. Along with the development of branding context, now branding has penetrated to many lines including in the development of one's self. This is then known as personal branding. This study looks into the analysis of personal branding teenagers represented by Gita Savitri. Gita Savitri is a teenage figure who is loved for his thoughts in dealing with many things about teenage life. One of the objectives of this research is to embody the teenager's perspective in defining her identity. This is necessary because self-existence is a fundamental thing that must exist in a person including teenagers. This research uses qualitative descriptive method supported by eight main concept personal branding Peter Montoya. The results show that personal branding Gita Savitri meets the eight major concepts and covers the three main elements of personal branding namely You, Promise and Relationship.
\end{abstract}

Keywords: personal branding, social media, teenagers, Instagram, Gita Savitri. 


\section{PENDAHULUAN}

Setiap orang memiliki ciri yang khas pada dirinya. Hal itu dapat dilihat, baik dari ciri fisik maupun nonfisik, yang melekat atasnya. Mulai dari bentuk wajah, postur tubuh, karakter, hingga bakat yang dimiliki. Ciri tersebut dinilai sebagai pembeda antara orang yang satu dengan yang lain. Hal tersebut pada akhirnya akan membentuk suatu keunikan diri yang tidak hanya sebagai pembeda, namun mulai dipahami sebagai upaya untuk mengembangkan diri. Termasuk di dalamnya adalah wujud eksistensi sebagai media aktualisasi diri.

Sebagaimana dinyatakan oleh Chaplin (2002:12), eksistensi merupakan cara untuk menujukkan keberadaan manusia, situasinya dalam dunia, kebebasannya memilih tujuan hidup, serta berusaha memahami arti kehidupannya sendiri. Eksistensi diri merupakan segala kemungkinan yang apabila direalisasikan dapat mengarahkan individu pada keberadaan autentik, yaitu manusia menjadi dirinya sendiri, mengambil tanggung jawab untuk menjadi dirinya sendiri dengan menyeleksi kemungkinankemungkinan yang ada dan disediakan dalam kehidupannya (Thompson, 2010).

Pada konteks ini, eksistensi yang dimaksud adalah yang dibentuk oleh kalangan remaja sebagai pembentukan jati dirinya. Lebih dari itu, pembentukan jati diri yang khas pada akhirnya disadari sebagai hal penting untuk menunjukkan potensi, terutama di era seperti sekarang ini yang penuh dengan kompetisi, menunjukkan potensi diri menjadi hal yang utama.

Atas alasan itulah memahami konsep personal branding menjadi hal penting sebagai cara untuk meningkatkan 'nilai jual' seseorang. Melalui personal branding, dapat disatukan hal-hal utama pada individu yang melibatkan skill, kepribadian, dan karakter yang dibungkus sebagai identitas yang kuat dibanding identitas diri orang lainnya (Montoya \& Vandehey, 2008).

Personal branding didefinisikan oleh Montoya dan Vandehey (2008) sebagai "taking control of how other people perceive you before they come into direct contact with you." Sementara itu, Mobray (2009) mendefinisikan personal branding sebagai "the ability to deliberately use attributes that demonstrate your capability to manage the expectations one will receive from an encounter with you."

Di era digital seperti sekarang ini, personal branding menjadi hal yang begitu lumrah dilakukan. Meski personal branding sudah ada sejak era-era sebelumnya, namun di era digital inilah tahapan personal branding menjadi hal yang begitu umum dilakukan, khususnya melalui internet. Berdasarkan laporan Wearesocial (Ramadhan, GNFI, 2018), pengguna internet dunia saat ini telah mencapai 4,021 miliar orang. Masih dalam laporan yang sama, dapat diketahui bahwa di Indonesia sendiri jumlah pengguna internet mencapai 132 juta orang. Jumlah tersebut menunjukkan bahwa lebih dari 50\% penduduk Indonesia telah mengakses internet. Fuady (2002) menyatakan kemajuan teknologi komunikasi meniadakan sekat dan jarak yang membatasi individu satu dan lainnya.

Internet merupakan salah satu bentuk media baru yang menawarkan beragam platform yang dapat dipilih sesuai kebutuhan dan keinginan penggunanya. Media sosial, sebagai salah satu bentuk media baru (new media) menjelma sebagai ruang yang diterjemahkan secara bebas oleh penggunanya. Seperti dinyatakan oleh Flew (2002) bahwa media baru memunculkan virtual reality. Realitas virtual ini merupakan fenomena yang sering muncul karena new media memungkinkan penggunanya untuk menggunakan ruang seluas-luasnya, 


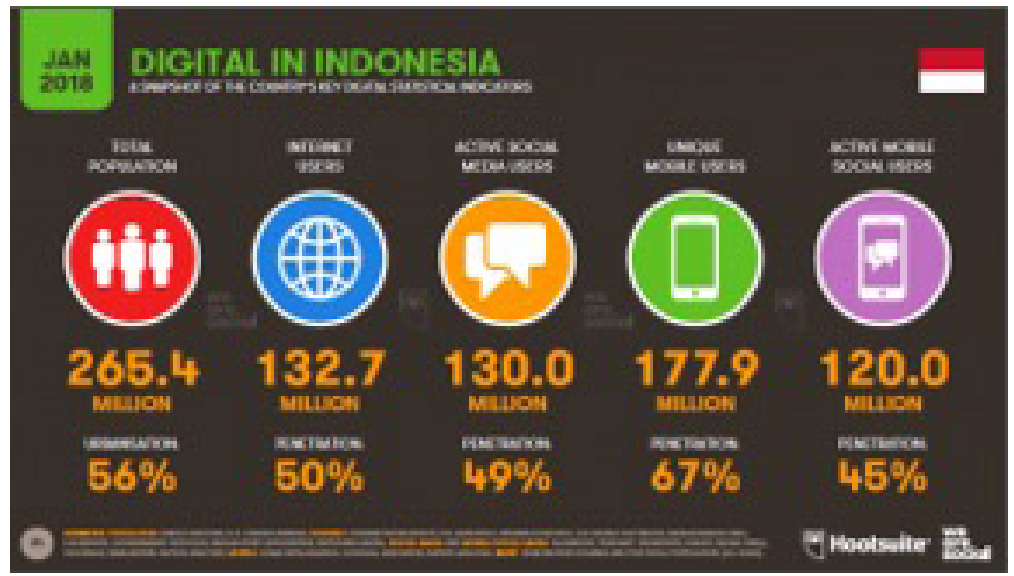

GAMBAR 1. Data Pengguna Internet di Indonesia

Sumber: http//firdausnetpreneur.com/ Februari, 2018.

memperluas jaringan seluas-luasnya, dan menunjukkan identitas yang lain dengan yang dimiliki pengguna tersebut di dunia nyata. Meski bukan tidak mungkin juga, bahwa identitas diri pengguna di dunia maya merupakan representasi dari identitas aslinya di dunia nyata.

Begitu banyak kegunaan media sosial sebagai bagian dari new media. Namun sayangnya, belum semua pengguna, khususnya pengguna di Indonesia, memanfaatkan media sosial mereka untuk hal positif secara maksimal. Padahal, akun media sosial dapat digunakan sebagai media pembentukan personal branding yang efektif dengan karakter daya jangkaunya yang luas.

Gita Savitri adalah salah satu dari sekian banyak remaja Indonesia yang telah memanfaatkan media sosialnya untuk menorehkan ide dan pemikirannya. Di saat remaja seusianya masih mengalami tahap kelabilan dalam pembentukan identitas diri, Gita Savitri justru telah mengetengahkan pemikirannya yang matang dengan gayanya yang tetap santai dan berjiwa muda layaknya remaja. Branding itulah yang menarik minat peneliti untuk mengetahui lebih dalam bagaimana personal branding Gita Savitri dibentuk melalui akun media sosialnya.

Instagram dipilih dalam penelitian ini karena menjadi salah satu media sosial yang saat ini begitu banyak digunakan di
Indonesia. Seperti yang dilaporkan We Are Social bahwa Indonesia menempati posisi sebagai salah satu negara terbesar pengguna Instagram dunia. Indonesia dalam peringkat pengguna Instagram mencapai 53 juta orang. Dalam hal ini, Indonesia menempati peringkat ketiga dunia setelah Amerika Serikat dan Brazil (Ramadhan, GNFI, 2018). Tidak hanya alasan itu, penelitian ini merujuk Instagram sebagai salah satu media yang digunakan dalam pembentukan personal branding mengingat data yang dilaporkan oleh We Are Social bahwa profil pengguna media sosial Instagram didominasi oleh pengguna di usia remaja.

\section{METODE}

Penelitian ini menggunakan metode deskriptif kualitatif untuk menjawab pertanyaan penelitian "Bagaimana pembentukan personal branding Gita Savitri melalui media sosial Instagram". Metode ini dipilih untuk menggambarkan secara mendalam apa yang ditemukan di lapangan berdasarkan data yang diolah dengan keabsahan triangulasi sumber. Metode kualitatif dipilih karena penelitian ini hanya memaparkan situasi atau peristiwa tertentu, bukan untuk menguji hipotesis atau memprediksi sesuatu (Rakhmat, 2009). Proses pengumpulan data dilakukan melalui sejumlah tahapan yakni tahap deskripsi, reduksi dan seleksi 


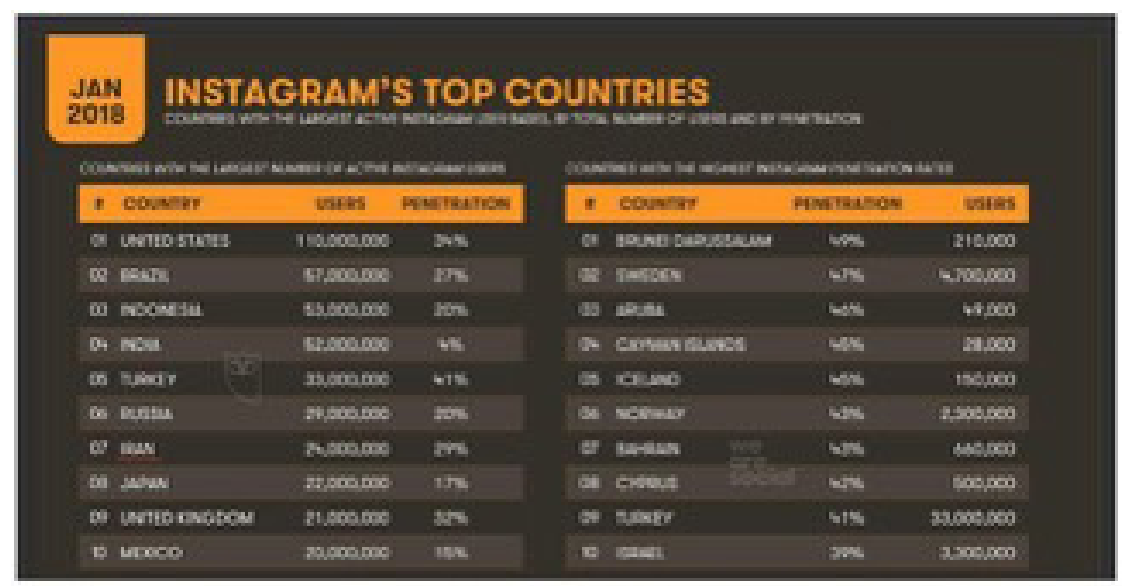

GAMBAR 2. Instagram's Top Countries

Sumber: http//goodnewsfromindonesia.com/ Februari, 2018.

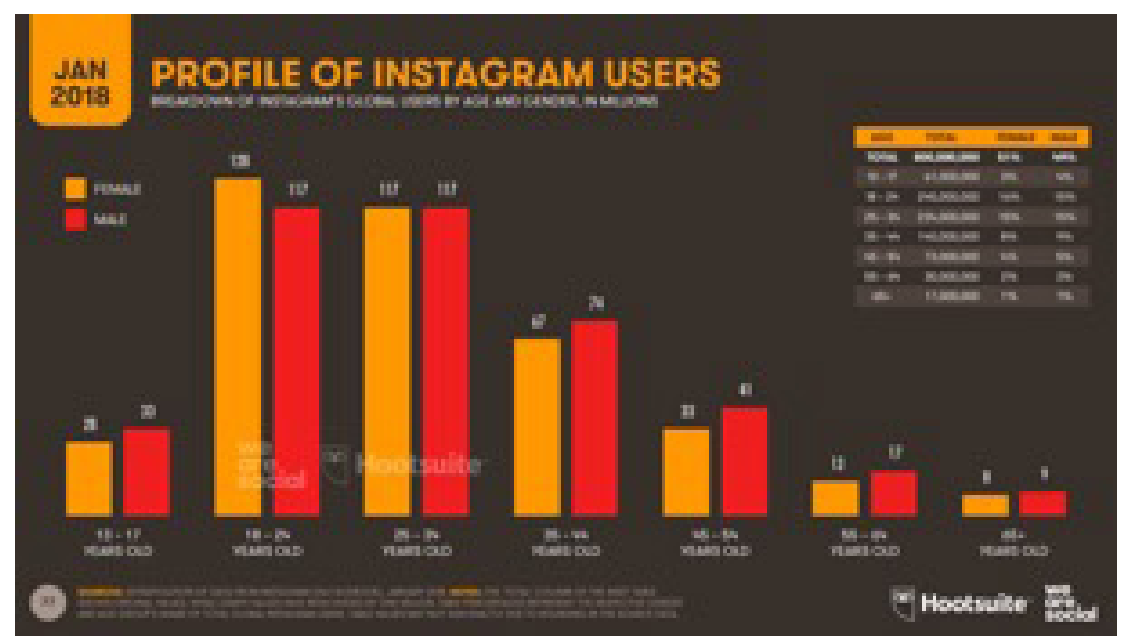

GAMBAR 3. Profil Pengguna Instagram

Sumber: htttp//wearesocial.com/. Februari, 2018.

di mana setiap tahapan tersebut dilakukan secara sirkuler dan tidak linier (Sugiyono, 2011). Peneliti melakukan pemilihan dan pemilahan data yang disesuaikan dengan kebutuhan data penelitian ini. Sebagai penelitian kualitatif, maka hasil dari penelitian ini bukan merupakan generalisasi dan sifatnya tidak berlaku umum.

\section{HASIL DAN PEMBAHASAN Pentingnya Personal Branding}

Sejauh ini, istilah branding atau pelabelan lebih akrab dilakukan di dunia pemasaran. Pelabelan dilakukan karena begitu banyak produk sejenis yang beredar, sehingga diperlukan pembeda bagi produk yang satu dengan produk yang lain. Hal itu bertujuan untuk membuatnya lebih menonjol dibanding produk sejenis lainnya. Prinsip dasar itulah yang kemudian diterapkan dalam konteks personal branding.

Di era persaingan seperti sekarang ini, semakin banyak individu yang memiliki keahlian yang sama. Oleh karena itu, perlu dibangun personal branding untuk mengenalkan keahlian seseorang agar lebih menonjol dibanding keahlian orang lainnya. Pada akhirnya, pembentukan personal branding tersebut dapat meningkatkan nilai jual seseorang atas keahlian yang dimiliki. Hal itu dapat terjadi karena standar diri seseorang dijadikan sebagai acuan dalam pengembangan dirinya sesuai dengan potensi yang dimiliki.

Lebih dari itu, personal branding 
juga dapat digunakan sebagai pembuka networking dengan individu lain dengan ketertarikan yang sama dalam suatu bidang tertentu. Tujuannya, prospek karier seseorang juga semakin terbuka lebar.

Personal branding dapat mengatur presepsi seseorang terhadap orang lain, dengan menceritakan pengalaman kepada orang lain secara natural sehingga orang lain berpikir bahwa persepsi tersebut dibangun dengan sendirinya (Montoya, 2002). Personal branding juga dapat dikatakan sebagai proses di mana seseorang dipandang sebagai sebuah brand (merek) oleh target market (Lair, Sullivan, dan Cheney, 2005:35). Dapat disimpulkan bahwa personal branding adalah suatu proses pemebntukan persepsi masyarakat terhadap aspekaspek yang dimiliki seseorang, di antaranya kepribadian, kemampuan, atau nilai-nilai, dan bagaimana stimulusstimulus ini menimbulkan persepsi positif dari masyarakat yang pada akhirnya dapat digunakan sebagai alat pemasaran (McNally \& Speak, 2002).

Menjadi hal yang patut disyukuri manakala kehadiran media sosial dengan karakteristiknya yang cepat dalam menyebarkan pesan dan memiliki jangkauan luas, dapat dijadikan sebagai media pembentukan personal branding seseorang. Ada banyak fitur yang dapat dimanfaatkan untuk membangun personal branding menjadi lebih kreatif dan menarik. Hal yang menjadi masalah kemudian adalah strategi pembentukan personal branding itu sendiri. Hal inilah yang masih belum banyak diketahui oleh banyak orang khususnya para remaja.

\section{Gita Savitri dan Media Sosial}

Gita Savitri Devi yang lebih dikenal dengan Gita Savitri adalah remaja asal Indonesia yang mendapat beasiswa untuk berkuliah di Jerman. Gita Savitri mendapat sorotan dari banyak khalayak atas pemikirannya, baik sebagai blogger, youtuber, maupun selebgram.

Penelitian ini lebih fokus terhadap penggunaan media sosial Instagram dalam pembentukan personal branding Gita Savitri. Sebagai selebgram, Gita memiliki karakter yang kuat. Hal itu ditunjukkan dengan konsistensinya yang tinggi terhadap konten kiriman yang dibagikan kepada para pengikutnya. Dengan jumlah pengikut yang cukup banyak yakni 560.000 folowers, Gita dapat menjangkau banyak khalayak dalam menyebarkan ide dan pemikirannya. Tidak sedikit kiriman Gita yang mendapat respons positif serta mampu memengaruhi pola pikir remaja lainnya agar lebih bijak dalam bertindak.

Melalui akun media sosialnya, Gita membagikan tulisan yang berisi pesan moral dengan dibalut cerita. Hal itu menjadikan apa yang dituturkan tidak terkesan menggurui karena lebih menonjolkan kesan santai khas gaya kawula muda. Santai, asyik, dan menarik, merupakan hal yang mencerminkan pembawaan Gita. Hal itulah yang memberikan nilai lebih atas dirinya sehingga banyak pesan moral pada setiap postingannya yang diterima baik para pengikutnya.

Sebagai contoh, ketika Gita Savitri menyampaikan pemikirannya untuk tidak sembarang memberi kepada pengemis. Gita bercerita di akun media sosialnya ketika sedang berada di kereta yang membawanya ke salah satu kota di Jerman. Pada saat pengemis meminta sejumlah uang namun dengan tegas Gita menolak. Hal itu dilakukan bukan tanpa alasan. Gita menuturkan bahwa menurut pengamatan dan pengalamannya, pengemis-pengemis yang sering ditemuinya itu acap kali menghabiskan waktu dengan meminum alkohol di area stasiun. Gita tidak ingin memberikan uangnya kepada pengemis itu karena itu sama artinya dengan mendukung si pengemis untuk kembali mengonsumsi 

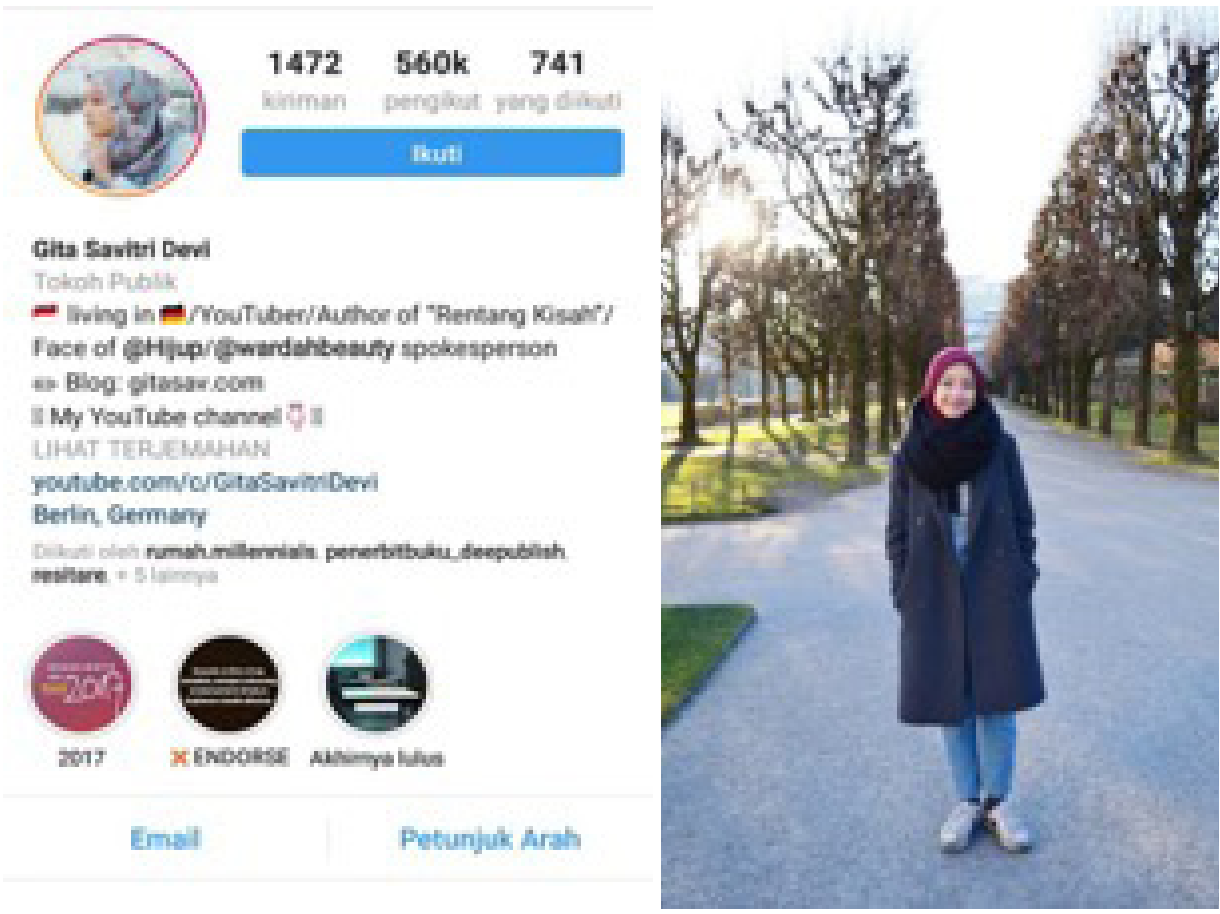

GAMBAR 4. Profil Akun Instagram Gita Savitri

Sumber: Instagram Gita Savitri, 2018.

alkohol. Gita menambahkan bahwa secara fisik, pengemis-pengemis tersebut masih muda dan bugar.

Pada kisah itu, Gita mengakhiri tulisannya dengan ajakan dan motivasi bagi kaum remaja untuk lebih semangat dalam memanfaatkan waktu untuk melakukan hal positif. Dari kisah tersebut, tidak sedikit follower yang menyatakan sependapat dengan pemikiran Gita.

Fakta tersebut sejalan dengan apa yang disampaikan oleh Ardianto (Aspikom-Komunikasi 2.0, 2011) bahwa media sosial sebagai media yang memiliki kekuatan sosial untuk memengaruhi opini publik yang berkembang di masyarakat. Penggalangan dan dukungan atau gerakan massa dapat terbentuk karena kekuatan media online. Apa yang ada di dalam media sosial terbukti mampu membentuk opini, sikap, dan perilaku publik/masyarakat.

Mengutip pernyataan Juju dan Sulianta (2010) bahwa media sosial merupakan kombinasi antara ruang lingkup elemen dunia maya dalam berbagai platform dengan kekuatan komunitas yang dibangun pada jejaring sosial. Apa yang dikomunikasikan di dalamnya memberikan efek "power" karena akses pembentukannya berupa teknologi sebagai media interaksi dalam bentuk teks, gambar, foto, audio, dan video. Hal tersebut juga melekat pada akun media sosial Instagram Gita Savitri sebagai media pembentuk personal branding. Khalayak dapat mengakses pemikiran Gita Savitri baik melalui teks, gambar, foto, maupun video yang dibagikan Gita dalam akun media sosialnya.

\section{Pembentukan Personal Branding Montoya}

Personal branding yang baik dapat terbentuk dengan memenuhi beberapa unsur utama. Peter Montoya (2002) merumuskan konsep pembentukan personal branding yang meliputi delapan unsur utama sebagai berikut:
(1) Spesialisasi (The Law of Specialization)
Bahwa personal branding dapat terbentuk dengan spesialisasi tertentu yang dimiliki oleh seseorang. Pada konteks penelitian 
ini dapat diketahui bahwa Gita Savitri membentuk personal branding dengan tulisantulisannya. Spesialisasinya sebagai remaja yang cerdas dan aktif dituangkan dalam setiap kiriman yang dibagikan melalui akun media sosial miliknya. Gita memiliki spesialisasi dalam bentuk teks, foto, dan video. Bahkan, spesialisasinya dalam menulis telah dibuktikan dengan diluncurkan buku perdananya berjudul Rentang Kisah yang langsung mendapat label best seller. Spesialisasi ini tentu berbeda dengan selebgram lain, misalnya selebgram dengan spesialisasi di bidang fashion, kuliner, dan lainnya.

(2) Kepemimpinan (The Law of Leadership)

Kepemimpinan dapat dibentuk melalui keunggulan, yakni dipandang sebagai seorang ahli dalam bidang tertentu. Memiliki kekuatan untuk mengarahkan mengenai hal tertentu melalui spesialiasi yang dimiliki. Demikian halnya pada konteks penelitian ini, bahwa Gita Savitri memiliki kemampuan untuk mengarahkan dan memimpin atau menggiring

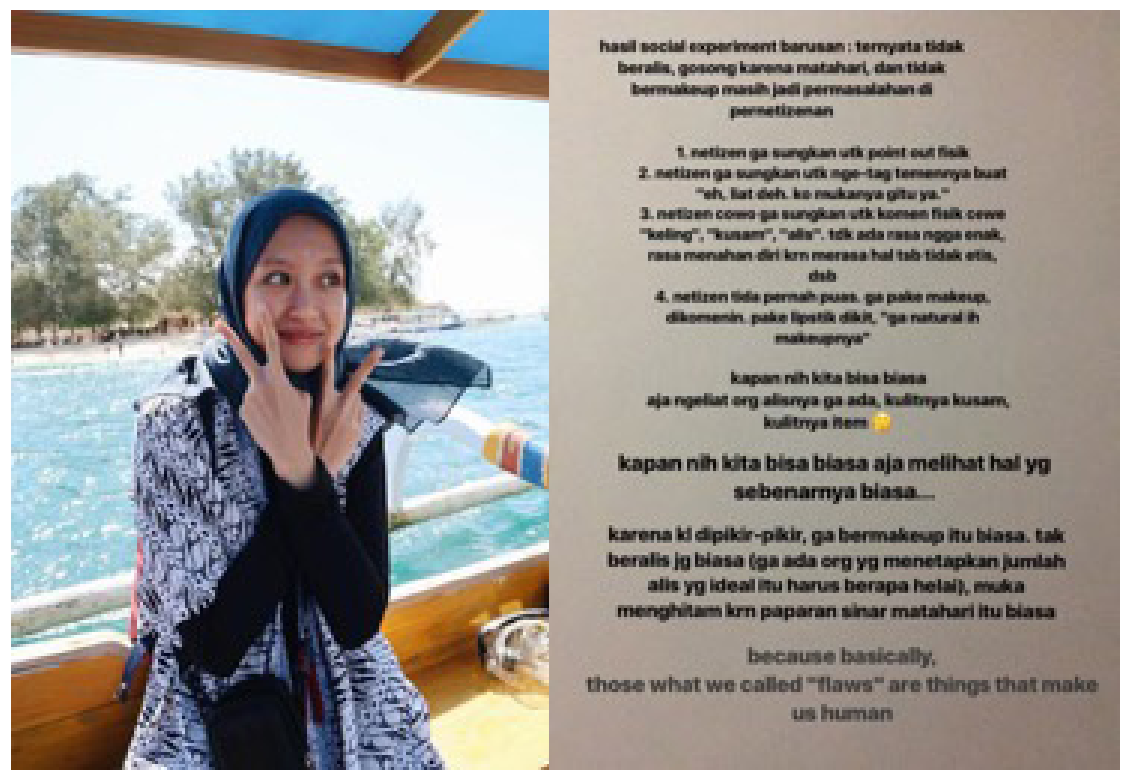

GAMBAR 5. Percobaan Eksperimen Sosial Gita Savitri

Sumber: Arina Yulistara, 2017 dalam https://wolipop.detik.com/ pengikutnya untuk menyepakati apa yang diutarakannya. Hal tersebut tampak dalam kiriman yang dibagikan di Instagram miliknya. Misalnya, pada saat Gita bermaksud untuk membagikan pemikirannya tentang kekerasan bukan fisik dalam menilai orang lain dalam kehidupan sehari-hari, Gita membuat sebuah eksperiman sosial di akun Instagramnya. Pada kasus itu, Gita menyoroti pendapat dan penilaian seseorang terhadap penampilan dirinya yang sengaja tanpa make-up.

Pada GAMBAR 5, Gita menunjukkan kemampuannya untuk menggiring dan memimpin pengikutnya dalam membentuk opini yang pada akhirnya mampu menjadi opini publik di kalangan khalayaknya. Opini yang dikirimkannya melalui instastory sebagai salah satu fitur yang ada di Instagram adalah kesimpulan yang dia kumpulkan berdasarkan respon khalayak yang ada di kolom komentar seperti berikut ini:

"Gpp muka rada keling ya kak ya, yg penting tangan sama muka masi putihan tangan," ujar@ azizzagusti. 
“Tua bgt,” tulis@aishaptr.

"Dah iteem," tambah @ amelnande.

"Hoo sengaja post gini biar banyak yg komen jelek trus ka gita bisa nyinyirin balik hahah nice move,"kata@edhimedhim.

$$
\text { "Jelek," ucap @ }
$$

bachtiarkenan.

"Ka gita alisnya telanjang" tulis@pinkaankrmy.

"@gitasav Gue ga pernah bilang body shaming bener, tapi dari kasus social experiment lo, terkesan kalo lo emang nyari2 tuh komen negatip. Buat nanti lo suarakan, agar sejalan dengan pemikiran dan hal yang beberapa hari ini jadi concern lo (tentang body shaming, sexist,etc). Nah cara lo 'tes ombak' seperti itu yang (menurut gue, sorry para fans 2 mbak Gita yang budiman) agak childish, sorry to say,"komentar@rianyer.

(3) Kepribadian (The Law of Personality)

Personal branding yang baik menggambarkan kepribadian individu dalam segala aspek, artinya bukan hanya kelebihan atau kesempurnaan, tetapi juga ketidaksempurnaan individu. Pada konteks ini, dapat dilihat bahwa sosok Gita sebagai remaja yang cerdas dan berpikiran luas tidak serta-merta mendapat dukungan dari para pengikutnya. Masih tetap ada yang memberikan penilaian negatif dan menganggap bahwa Gita memiliki kepribadian yang ambisius. Tidak hanya itu, pada saat buku pribadinya diluncurkan, muncul juga anggapan bahwa Gita sengaja memanfaatkan namanya yang memang sudah kondang sebelum buku itu dipasarkan, sehingga label sebagai penulis buku best seller dianggap hanya sebagai bentuk keberuntungan yang memang sudah memiliki 'massa' cukup banyak di akun media sosialnya. Anggapan tersebut merupakan bukti bahwa personal branding menggambarkan kepribadian individu yang meliputi banyak aspek, bukan hanya pada kelebihannya saja namun juga pada kekurangan atau sisi negatifnya.

(4) Perbedaan (The Law of Distinctiveness)

Sebagaimana deferensiasi yang diterapkan padasetiapproduk, dalam pembentukan personal branding yang efektif juga diperlukan hal yang sama. Diperlukan kesan yang kuat untuk menjadi berbeda dari orang lain dalam bidang atau bisnis yang sama. Pada konteks penelitian ini, hal yang membuat Gita berbeda dengan selebgram remaja lainnya adalah hal-hal yang disorot Gita dan cara dia menyikapinya. Gita cukup berani dalam menuangkan pemikirannya dan tidak canggung dalam membagikan opininya. Kiriman yang dibagikan juga disertai ajakan untuk melakukan halhal positif. Tidak hanya itu, kesan kuat yang diciptakan oleh Gita juga dengan caranya yang tetap asyik sebagai remaja sehingga tidak ada kesan menggurui. Hal inilah yang menjadikannya memiliki daya tarik lebih kuat dan berbeda dibanding selebgram remaja lainnya.

(5) Kenampakan (The Law of Visibility) Salah satu strategi membentuk personal branding yang efektif adalah dengan melakukannya penuh konsistensi atau terus-menerus sehingga personal branding orang tersebut menjadi dikenal. Gita Savitri secara sadar dan konsisten mempublikasikan dirinya melalui kiriman dalam bentuk teks, foto, maupun video. Gita melakukannya 
dengan konsistensi yang cukup tinggi. Hal yang dilakukannya secara terus-menerus itulah yang pada akhirnya membentuk personal branding atas dirinya.

(6) Kesatuan (The Law of Unity)

Kesatuan yang dimaksud dalam pembentukan personal branding adalah kehidupan pribadi yang sejalan dengan apa yang dibentuk dalam personal branding seseorang. Pada konteks penelitian ini, Gita berusaha menjadikan kehidupannya bersinergi. Apa yang ada dalam kehidupannya sehari-hari sebagai realita pengalaman personalnya sejalan dengan apa yang dia bagikan melalui akun media sosialnya. Oleh karena itu, terbentuklah kesatuan yang bersinergi dan tidak saling bertolak belakang. Hal ini pada akhirnya dapat memperkuat citra yang muncul di mata khalayak atas personal branding yang dibentuk oleh Gita Savitri.

(7) Keteguhan(The Law of Persistence) Pembentukan personal branding seseorang tidak akan mungkin terjadi hanya dalam satu malam. Diperlukan waktu yang cukup lama sehingga seseorang harus memiliki keteguhan terhadap personal branding yang dibentuk sejak awal tanpa ada ragu untuk mengubahnya. Jika hal tersebut terjadi, maka akan bertolak belakang dengan prinsip konsistensi yang sudah dijelaskan di awal. Pada konteks penelitian ini, Gita secara sadar telah membentuk personal branding-nya dengan penuh keteguhan. Meskipun tidak sedikit komentar pedas yang menyerangnya, namun Gita tetap pada jalan yang telah dipilihnya.

(8) Maksud baik (The Law of Goodwill) Personal branding seseorang akan memiliki pengaruh besar bagi orang lainnya jika dipersepsikan secara positif oleh orang-orang di sekitarnya. Pada tahap ini, Gita dapat dikatakan telah memiliki ciri yang khas dalam memublikasikan dirinya dalam menyampaikan ide dan pemikirannya dibanding remaja lain pada umumnya. Hal ini membuat gaya Gita dapat diterima dan dipahami sebagai sebuah ciri khas di mata publiknya.

\section{Tiga Elemen Personal Branding}

Dalam membangun personal branding, tentunya diperlukan elemenelemen utama yang harus saling terintegrasi. Berikut adalah elemen utama dalam membangun personal branding menurut Montoya dan Vandehey (2008):

(1) You

Istilah you yang dimaksud dalam hal ini adalah seseorang itu sendiri. Seseorang dapat membentuk personal branding melalui polesan (strategi) dan metode komunikasi yang disusun dengan baik. Strategi dan metode komunikasi tersebut dirancang untuk menyampaikan dua hal penting kepada khalayak mereka, yaitu:

- Siapakah dirinya sebagai seorang pribadi?

- Spesialisasi apa yang dimiliki/ dilakukannya?

Pada dasarnya, personal branding adalah sebuah gambaran mengenai apa yang masyarakat pikirkan tentang seseorang. Hal tersebut mencerminkan nilai-nilai, kepribadian, keahlian, dan kualitas yang membuat seseorang berbeda dengan yang lainnya.

Pada konteks penelitian ini, Gita Savitri telah mampu mendefinisikan dirinya sebagai remaja berprestasi yang dibuktikan dengan perolehan beasiswa untuk berkuliah di Jerman. Gita Savitri juga telah membentuk personal branding atasnya sebagai 
sosok remaja yang aktif dan berusaha untuk selalu membagikan hal positif kepada remaja lainnya.

Dari sisi spesialisasi, Gita Savitri menyadari bahwa dirinya memiliki kemampuan yang baik dalam menulis. Hal tersebut ditunjukkan dari kiriman-kirimannya tidak hanya di Instagram tetapi juga di blog miliknya tentang ide dan pemikirannya yang terkumpul dalam sejumlah tulisan. Bahkan kumpulan tulisan tersebut telah berhasil mengantarkannya menjadi seorang penulis profesional. Hal tersebut dibuktikan ketika dirinya resmi meluncurkan buku perdananya berjudul Rentang Kisah. Karyanya tersebut semakin memperkuat spesialisasi dirinya dalam pembentukan personal branding yang kuat.

(2) Promise

Personal branding adalah sebuah janji, sebuah tanggung-jawab untuk memenuhi harapan yang timbul pada masyarakat akibat dari personal branding itu sendiri. Pada konteks penelitian ini, Gita Savitri sebagai remaja tetap diharapkan tampil di mata khalayaknya sepatutnya seorang remaja seusianya. Mulai dari penampilan fisik hingga cara berpikirnya. Jika dalam mengedepanan pemikiran Gita sudah sangat diterima dengan baik, maka dari sisi penampilan Gita juga mendapat pengharapan dari khalayaknya. Janjinya setelah berhijrah dan memantapkan diri menutup aurat, harus selalu ditepati dalam setiap kesempatan. Ada satu tanggung-jawab moral yang diemban.

Dari sisi penampilan tidak hanya sampai di situ saja. Apa pun yang dikenakan termasuk pakaian ataupun make-up yang dipilih harus memenuhi janji sebagai tanggungjawabnya kepada pengharapan dan penilaian khalayak. Ketika personal branding yang diusungnya, yakni sebagai remaja yang cerdas dan aktif, maka apa yang dikenakan dan make-up yang dipilih harus sesuai dengan usianya sebagai remaja. Harus sesuai dengan brand yang sudah melekat pada dirinya. Sejauh ini, apa yang ditampilkan oleh Gita Savitri dalam unsur bersikap, berperilaku, dan berpenampilan sudah cukup memenuhi standar 'promise' yang sesuai dengan label atas dirinya di mata khalayak.

(3) Relationship

Personal branding yang baik akan mampu menciptakan suatu relasi yang baik dengan klien/khalayak. Semakin banyak atribut-atribut yang dapat diterima oleh klien dan semakin tingginya tingkat kekuasaan seseorang, menunjukkan semakin baiknya tingkat relasi yang ada pada personal branding tersebut. Pada konteks penelitian ini, hubungan antara Gita Savitri dengan khalayaknya dapat dikatakan telah tercipta dengan baik. Meski tidak dipungkiri bahwa tetap saja muncul hubungan yang kurang baik, namun hal tersebut masih dapat ter-cover dengan stabil. Gita Savitri dituntut oleh khalayak untuk memberikan respons positif terhadap stimulus dalam bentuk apa pun dari khalayaknya.

\section{SIMPULAN}

Pada penelitian ini dapat disimpulkan bahwa sebagai seorang remaja, Gita Savitri telah membentuk personal branding dengan cukup baik. Indikator baik tersebut berdasarkan delapan unsur pembentuk personal branding Montoya yang telah diterapkan dalam pembentukan personal branding 
Gita Savitri melalui akun media sosialnya. Tidak hanya itu, terdapat tiga elemen dasar personal branding yakni you, promise, dan relationship yang juga telah diadopsi oleh Gita Savitri. Berdasarkan hasil dari penelitian ini dapat diketahui bahwa Gita Savitri memiliki karakter yang khas dan kuat dalam membentuk personal branding sebagai remaja yang cerdas, berpikir visioner, asyik, dan hangat.

\section{DAFTAR PUSTAKA}

Aspikom, Komunikasi 2.0. (2011). Yogyakarya: Mata Padi Pressindo.

Chaplin, J.P. (2002). Dictionary of Psychology. New York. Dell Publishing Co.Inc.

Flew, T. (2002). New Media: An Introduction. New York: Oxford University Press.

Fuady, M. E. (2002). Surat Kabar Digital sebagai Media Konvergensi di Era Digital. Jurnal Mediator, 2 (1), halaman 55-61.

Juju, D. dan Sulianta, F. (2010). Branding Promotion with Social Network. PT. Elex MEdia Komputindo: Jakarta.
McNally, D., \& Speak, K. D. (2002). Be Your Own Brand: Achieve More of What You Want by Being More of Who You Are. San Francisco: Berrett-Koehler Publishers.

Montoya, P. dan Vandehey, T. (2008). The Brand Called You: Make Your Bussiness Stand Out in a Crowded Market Place. USA: McGraw-Hill.

Montoya, P. (2002). The Personal Branding Phenomenon: Realize Greater Influence, Explosive Income Growth and Rapid Career Advancement by Applying the Branding Techniques of Michael, Martha \& Oprah. USA: Peter Montoya Incorporated.

Rakhmat, J. (2009). Metode Penelitian Komunikasi. Bandung: PT Remaja Rosdakarya.

Sugiyono. (2011). Metode Penelitian Kuantitatif, Kualitatif dan $R \& D$. Bandung: Afabeta

Thompson, J. A., Strickland, A. J. And Gamble, E.J. (2010). Crafting and Executing Strategy, Seventeenth Edition, New York: Mc Graw- Hill/ Irwin, Inc. 